\title{
Facing Stigma: A Study of Stigma Message Effects about COVID-19 Sufferers on Marked Supporters in Kauman Village Yogyakarta
}

\author{
Chairunnisa Widya Priastuty ${ }^{1}$; Pawito $^{2}$; Andre N. Rahmanto ${ }^{2}$ \\ ${ }^{1}$ Student, Magister Communication Science Program, Faculty of Social Science and Political Science, Universitas \\ Sebelas Maret, Indonesia \\ ${ }^{2}$ Lecturer, Magister Communication Science Program, Faculty of Social Science and Political Science, Universitas \\ Sebelas Maret, Indonesia
}

http://dx.doi.org/10.18415/ijmmu.v8i8.2832

\begin{abstract}
The stigma about COVID-19 sufferers along with the effects of stigma messages is now increasingly attached to the lives of people, especially those living in the environment around COVID-19 sufferers and or survivors. Not only for sufferers, said stigma today is also attached to marked supporters because of its existence that has a close relationship with sufferers. Stigma arises as a result of the community's complete lack of understanding of COVID-19 itself. The effect is not missed in influencing the communication between individuals and each other. This also happens in Kauman Village Yogyakarta where stigma and its effects are felt by many marked supporters. This is unique because so far the stigma has hit the sufferer more often, but not in this case, the stigma is more about marked supporters. Seeing the phenomenon, the question arises how stigma affects the relationship of marked supporters to the community in Kauman Village Yogyakarta after the message of stigma. This study uses a case study method. The focus of this study is the stigma about COVID-19 sufferers who hit marked supporters and the effect of stigma messages that appear on marked supporters after being hit by stigma messages. The findings suggest that the effect of stigma messages on each individual results in different findings depending on how the acceptance of the stigma message is then able to influence the interpersonal relationship between the marked supporters and the public in general.
\end{abstract}

Keywords: Stigma Communication; Stigma Message Effects; COVID-19; Marked Supporters; Sufferers

\section{Introduction}

It has not felt like more than a year, Corona Virus Disease-2019 (COVID-19) seems to still be volatile around the world, especially in Indonesia. This unending pandemic situation forced the world to experience the worst health crisis in pandemic history since 1918 (Moreno, Fuentes-Lara, Navarro, 2020). Recent cases have increased when the vaccination process has begun to make Indonesia should be in a condition that is increasingly choked because since the first time the virus has not experienced a significant decrease, making Indonesia ranked $1^{\text {st }}$ with the highest cases of COVID-19 in the Southeast Asia region (inews.id). The Ministry of Health of the Republic of Indonesia (covid19.go.id) reported that, as of January 2021, Indonesia has confirmed 965,283 cases of COVID-19, of which 781,147 patients recovered and 27,453 died. This indicates that COVID-19 actually has a fairly high cure rate compared to deaths that have occurred. That is, although we need to fight this virus, actually we just need to be vigilant and do not need to feel excessive fear and anxiety but also not then underestimate this disease until then off guard because 
the virus really exists and potentially deadly. Only for prevention can be pursued to be done by complying with strict health protocols in accordance with the recommendations of the government.This reality doesn't seem to be in line with what's happening on the field. The structure of news presented by both conventional and online media generally instead of preaching negative news trends rather than presenting positive news to the public. The media tends to take advantage of people's fears of viruses they don't yet fully know and recognize. This is because the media understands very well the patterns of people who tend to be more interested in accessing negative news than positive news. Since Indonesia officially declared the emergency status of COVID-19 on March 15, 2020, the media began frying various news with a point of view according to the needs of the media itself, ranging from the exploitation of the condition of COVID-19 sufferers who are undergoing treatment, who have died, even during the funeral process was dramatized by the media to ignite fear in the lay community. From people's fear of this virus coupled with the continuous exposure of negative news to the community, a new problem arises that is also no less troubling, namely the emergence of stigma against COVID-19 sufferers.

The stigma that arises as an effect of negative news seems to reinforce the fear of society where there is a view from the community that feels the need to stay away from sufferers because they feel threatened by their existence, the lack of factual information about people with COVID-19, and the lack of trust from the community, especially from marginalized groups, people with disabilities, and groups that are economically incapable of authority because they often get discrimination from public services even before COVID-19 came to an outbreak (suara.com). Stigma itself in understanding an outbreak is the process of labeling, stereotypes, discrimination, and the threat of loss of status to sufferers (who.int). More than labeling, if this stigma is allowed to flourish without being resolved it will add new problems because efforts in breaking the chain will be more difficult because the long-term impact is evident where those who experience symptoms or have close contact with sufferers will be afraid to conduct tests and treatment because of the fear of stigma that may be carried out and treated improperly (tirto.id). This is in line with what the Expert Team of the Task Force on Handling COVID-19 in the Field of Behavior Change, Turro Wongkaren, (nasional.kompas.com) stated that until the end of 2020 the community seems to still provide negative stigma to COVID-19 sufferers which causes them not to be open to the symptoms that are being felt. Covering up the actual condition is a real impact of growing stigma in which people tend to hide it because it avoids discrimination, prevents people from seeking medical treatment, and stops them from behaving healthily (Abdillah, 2020).

The number of cases of stigma that has sprung up in various regions of Indonesia, one of which also occurs in the Special Region of Yogyakarta which is famous as a city whose people are attached to the attitude of mutual cooperation and guyup rukun (harmony) maintain togetherness until known as the city of tolerance (biroumum.jogjaprov.go.id) seems in the situation of the COVID-19 pandemic this time must be willingly hit so that stigma is inevitable. One of the cases that occurred was when the Bantul District Government will conduct rapid tests on all traditional market traders claiming difficulties because traders are worried about being exposed to negative stigma if it is found that among them are reactive (jogja.tribunnews.com). In relation to the case, in the city of Yogyakarta itself also seems to not escape the spread of stigma in the community, namely Kauman Village Yogyakarta which has a typical decent and comfortable residence (Sativa, 2012) and the character of its community that is recognized by its citizens as a guyup (pillars) community, thick with Javanese Culture (Sultan Palace of Yogyakarta) and Islam, and a comfortable, peaceful, and cool environment is also beset by stigma issues in the community.

Uniquely, unlike most cases of stigma that often concerns sufferers directly, in Kauman Village Yogyakarta, the growing stigma message is more felt by supporters of COVID-19 sufferers or marked supporters who come from families of COVID-19 sufferers and or people who have close relationships or are in close contact with COVID-19 sufferers. The stigma they feel then affects the interpersonal relationship between COVID-19 sufferers to the community environment after the stigma is exposed. From the existing problems, this study narrows to the issue of how stigma arises and the effect of stigma messages about COVID-19 sufferers on supporters of COVID-19 sufferers as marked supporters in Kauman Village Yogyakarta. By conducting a study of the effect of stigma messages that appear on flagged supporters, it will be seen what solutions can be done so that stigma can be suppressed and restore harmony of interpersonal relationships in society, especially for those affected by stigma in order to not continue to be ostracized. This study uses qualitative approach with case study method so that it will be known the extent of stigma regarding COVID-19 sufferers can have a real impact on the environment in general and the relationship between people in particular. 


\section{Research Theory}

The effect of stigma messages is part of the communication theory about stigma that examines the impact of the behavior of parties after exposure to stigma messages. Goffman (Littlejohn \& Foss, 2009) argues that interactions between people who are exposed to stigma and who are not exposed to stigma will inevitably create a strained relationship in which the people involved need to deal with the emotions, thoughts, and behaviors associated with stigma. Tension is the result of emotions that occur when trying to communicate with each other. To clarify the effect of the resulting stigma message, each party inevitably has its own strategy to form the right interpersonal relationships. There are various actions introduced by addressee in response to stigma messages received when it comes to acting as communicators.

When discussing the effects of stigma messages, there are three parties that are then classified to see how each party establishes communication after exposure to stigma messages. The three parties involved in the effects of stigma message are effects on the marked and labeled, effects on the unmarked and unlabeled, and marked supporters (Smith in Littlejohn \& Foss, 2009). Specifically in this study, the effect of stigma messages that will be studied more deeply is about the effect of stigma messages about COVID-19 sufferers on marked supporters. This is because the field findings show that marked supporters consisting of families of COVID-19 sufferers and or people who have close or close contact with COVID19 sufferers are more exposed to stigma messages than COVID-19 sufferers themselves. Exposure to the stigma message they receive more because of the presence of those who remain in Kauman Village Yogyakarta to carry out self-isolation as part of the local government's health protocol procedures to remain isolated at home despite being declared negative for safety and comfort together seems often misinterpreted by the public at large because of a lack of understanding coupled with incorrect issues regarding the condition of marked supporters where $\mathrm{m}$ public society does not often equate the situation and condition of marked supporters with COVID-19 sufferers as being marked and labeled.

So seeing the effect of stigma message from marked supporters about COVID-19 sufferers becomes interesting because even people who are not sick just because it is close to the sick are considered the same as the sick. Research that focuses on people with COVID-19 is certainly not a little but talking about marked supporters seems to need to be highlighted more because this can be a sign that so important this stigma to be immediately dissolution because if continuously left will be as dangerous as the existence of the corona virus itself. Where the sick will get sicker is mentally and physically ill.

Back in the explanation of this theory, the effect on marked supporters may be two things that arise when communicating with others. Individuals can implement communication strategies such as those that are marked and labeled, such as withdrawal that is the action taken selectively exposing themselves only to those who accept conditions associated with discriminatory labels, secrecy that is hiding the label's marks and status can trigger group stigmatization, and or education that is trying to provide information and reveal about the status of labeling that is carried. Alternatively, the person concerned covers the confidentiality of COVID-19 sufferers from the general public so that the sufferer is not stigmatised and he/she as the closest person also does not get stigmatized so that there is privacy management of communications conducted by marked supporters.

\section{Methods}

The method used in this study is case study with qualitative approach. The selected research location is Kauman Village located in Ngupasan Village, Gondomanan District, Yogyakarta City. This village was chosen because there are cases of stigma about COVID-19 sufferers that occur, especially those experienced by marked supporters. The data collection techniques in this study use in-depth interview techniques conducted in person or face-to-face in February 2021. Informants in this study were chosen using purposive sampling techniques as sampling techniques that support COVID-19 sufferers or marked supporters who come from families of COVID-19 sufferers and or people who have close relationships or close contact with COVID-19 sufferers living in Kauman Village Yogyakarta in accordance with the selected research location so that informants must live in Kampung Kauman Yogyakarta. 


\section{Result and Discussion}

Through the data collected during an in-depth interview conducted in February 2021 related to the effect of stigma messages about COVID-19 sufferers on marked supporters in Kampung Kauman Yogyakarta shows that from the exposure of 3 informants (AH, WW, and AP) who were successfully met and willing to be interviewed in the field, they claimed there was a stigma that actually hit them as marked supporters. In addition, there are two dominant stigma message effects that appear after the stigma message about COVID-19 sufferers. From the effect of the stigma message that arises then determine the interpersonal relationship between marked supporters and society in general. Communication that occurs shows mixed results, some then return to the way they were and some later changed because of the attitude taken by supporters in communicating with the public in general because of trauma with the message of stigma felt. From the findings that have been presented, for further analysis will be discussed through two sub-chapters in more detail.

\section{Stigma about COVID-19 Sufferers on Marked Supporters}

Stigma seems not only directed to people with COVID-19, even for marked supporters, stigma is also received. The form of stigma received is even more felt by marked supporters than sufferers because COVID-19 sufferers are on average rushed to the COVID-19 shelters that have been provided and families of COVID-19 sufferers are advised to do self-isolation in their homes despite the negative results. Even one of the informants claimed that while she was still undergoing self-isolation, she heard residents reluctantly pass in front of his house so chose to walk to pull over and stay away from her house.

\section{"Iya, ada. Setelah maghrib, ada beberapa orang lewat depan rumah dan mereka bilang, "ini COVID... ini COVID” kemudian mereka berjalan cepat dan berjalan mepet di seberang rumah tidak mau lewat depan rumah persis."}

["Yes, there is. After maghrib, there were some people passing by the front of the house and they said, "this is COVID... this is COVID" then they walk fast and walk across the house do not want to pass in front of the house exactly."] (Interview with AH on February $23,2021)$.

Another with the merchant, WW. She claimed to have been avoided by buyers because of a growing issue that she also contracted because of contact with a husband friend who happened to be positive.

\footnotetext{
"Saya padahal negatif, namun warung saya sepi karena pembeli takut, tahunya saya juga positif karena bersinggungan dengan teman suami, padahal hasil saya jelas negatif. Sakit sekali sangsi sosial ini. Saya tidak sakit, hanya karena bersinggungan saja sudah dikira sama."

["I am negative, but my stall is deserted because the buyers are afraid, which they know I am also positive because of contact with my husband's friend, when my results are clearly negative. It hurts a lot because it's thought to be sick. I'm not sick, just because it's related it's been misinterpreted for the same thing."'] (Interview with WW on February 23, 2021).
}

From the stigma received by marked supporters shows that the general public's lack of understanding and fear of this new disease creates a stigma that easily arises and unpleasant behaviors occur. What the informants receive is basically a form of stigma that is unwittingly by the public that they have committed exclusion and discrimination against people who even themselves do not know the real condition. With minimal information and inedible issues that certainly develop in society, stigma is inevitable and from the stigma received then the effect of stigma message is clearly emerging from marked supporters that will be discussed in more detail in the next sub-chapter.

\section{Stigma Message Effects about COVID-19 Sufferers on Marked Supporters}

In the effect of stigma message, the tendency of the effect that arises is that informants tend to withdraw, education, and or even a combination of both. Secrecy and privacy management of 
communications are not chosen because it cannot be attempted when living in the same environment as society in general. This is because COVID-19 sufferers cannot choose to keep their status secret in Kampung Kauman Yogyakarta where according to health protocol procedures whatever the circumstances, local authorities must know and be followed up immediately so that as marked supporters it is also very difficult to keep the status of their family or closest people from the community.

Informant who choose to withdraw from the environment or withdrawal after getting a message of stigma is generally caused by feelings that is uncomfortable with the treatment of local residents so choose to be quiet and avoid from the community to suppress the stigma obtained even after the quarantine is over and there is no stigma that develops but she still chooses to reduce the intensity outside.

"Saya memilih untuk mengurangi keluar rumah. Meski sekarang sudah biasa, tapi saya malas untuk menjelaskan bagaimana kondisi saat ini. Saya yang penting, saya tidak mau cari tahu, pokoknya saya di dalam rumah, rumah saya sendiri, beli sesuatu dengan uang saya sendiri, sudah saya berpikir seperti itu. Daripada imun saya drop, saya pilih tidak terlalu banyak keluar, karena saya juga tidak mau dijauhi orang."

["I chose to cut back on getting out of the house. Although now it is common, but I am lazy to explain how the current condition. The important thing is I don't want to find out, anyway I'm in the house, my own house, buy something with my own money, I've thought that way. Instead of my immune drop, I choose not to go out too much, because I also don't want to be shunned by people.”] (Interview with AH on February 23, 2021).

Unlike WW, this informant tends to do education because of the need for her to straighten out the public's view of the actual condition. Because she worked as a trader, the choice to educate after being exposed to stigma became a tendency chosen as a marked supporter. The informant loudly refused to close the privacy that she had been in close contact with the sufferer and chose to educate the public.

"Saya tetap aktif dalam mengedukasi orang-orang yang memberi stigma terhadap saya. Saya memilih edukasi karena dengan demikian saya bisa menginformasikan bahwa saya baik-baik saja meski bertemu dengan penderita. Kemudian saya buktikan dengan hasil tes saya yang negatif."

["I remain active in educating people who stigmatize me. I chose education because I was able to inform that I was fine even though I met the sufferer. Then I proved with my negative test results."] (Interview with WW on February 23, 2021).

In addition to the two findings, there is also a tendency to effect stigma messages that appear on marked supporter tend to a combination of two effects at once, namely withdraw from the community or withdrawal but while educating the community to straighten the views and understanding of the community to the existence of those who can not be equated with COVID-19 sufferers.

"Ini di kampung sehingga saya memilih untuk berdiam diri saja di rumah karena tidak enak dengan warga kampung. Dibanding mendapat stigma yang lebih lagi, saya lebih memilih untuk banyak diam namun ketika ada kesempatan saya juga mengedukasi masyarakat mengenai kondisi saya dan kondisi adik saya. Saya juga kadang keluar tidak karantina seperti adik saya karena kamar kami berbeda dan saya juga harus kerja antar catering makanan, di situ saya biasanya melakukan edukasi agar masyarakat tidak salah kaprah dan makin salah dalam menilai."

["This is in the village so I chose to just stay at home because it is not good with the villagers. Instead of getting more stigma, I prefer to be quite a lot but when there is an opportunity I also educate the public about my condition and my brother's condition. I also sometimes go out not quarantine like my brother because our rooms are different and I also have to work between catering food, there I usually do education so that the public does not mislead and increasingly wrong in judging."] (Interview with AP on February 25, 2021).

From the exposure shows that marked supporters in fact have a different effect of stigma message according to how they receive the message stigma. In other words, receiving different messages certainly has different effects. So from 3 informants the tendency to effect the stigma message is also different. But 
the important thing that needs to be underlined is that marked supporters who should get the same treatment as the general public is known to also get stigma from the public to cause an effect that affects their interpersonal relationships that are disturbed with the general public. This if left unchecked will certainly affect the quality of communication and cause the boxed marked supporters of the social environment that should not be treated differently. If in other cases found such as informant $\mathrm{AH}$ who then chooses to withdraw continuously from the environment will certainly interfere with social life in general and the quality of life of a person in particular because it feels alienated.

\section{Conclusion}

From the results and discussions that have been discussed before shows that stigma is very attached to a disease and plague. After a long time often used in the use of HIV/AIDS and LGBT, nowadays stigma is also increasingly used in line with the case of COVID-19 which also continues to increase. Whereas unwittingly from the effect of stigma messages that have been discussed before starting from the effect of stigma messages can affect in various ways and have a long-term impact. Starting from the fear of society to be honest about what is felt for fear of stigma to a crisis of confidence and a decrease in the quality of life of someone who is stigmatized for feeling uncomfortable with the surrounding environment. From the effect of stigma message can also damage a person's interpersonal relationship as happened to the informant $\mathrm{AH}$ where after the stigma has been gone she chose to keep a distance with the environment for fear of being exposed to stigma again. If this continues to be allowed, then the stigma itself is as dangerous as the virus itself.

Speaking of the theory used, the effect of stigma message says that there are two possibilities that can arise but it turns out that with the case of COVID-19, especially in Kauman Village Yogyakarta with procedures that need to be adhered to, the possibility of stigma message effect that arises is only one possibility, namely withdrawal, secrecy, or education. Just like the effects that appear on the marked and the labeled. And for the case of COVID-19 that is indeed monitored by the government, keeping secret the status of the disease that is being suffered is very unlikely to be done so that anyone who intersects will still be tracked especially the 3T procedure (testing, tracing, treatment) that needs to be done so that marked supporters as people who have close contact with sufferers also can not keep their status from the public. Reflecting on the social symptoms that occur in Kampung Kauman Yogyakarta where patients are treated in special shelters while marked supporters in self-isolation in the house where living in the middle of the community causes stigma about COVID-19 sufferers, it is more common for marked supporters than sufferers because of life and direct contact with the community so that people's fears are directly felt and heard by marked supporters.

Practical advice that can be given is that the Government should not only focus on the spread of corona virus alone but the social environmental impact that is also caused needs to be considered and given attention as well. Socialization about removing stigma should be increasingly encouraged because COVID19 is not a disgrace and no sufferers and marked supporters want it. So far, the Government has advised more prevention efforts but the effects that have arisen due to COVID-19 are still not noticed. From the findings that exist although still far from perfect and still need to be expanded with similar follow-up research in various regions, it still needs to be a concern because the impact of stigma is not like a disease that can be cured and lost, the impact of stigma can damage and undermine one's quality of life. This needs to be done as a joint effort in strengthening the essence of humanity in saving society from the paradox of humanity (Junaedi, 2020). In other words, efforts to prevent COVID-19 need to be accompanied by efforts to suppress the stigma that is beginning to flourish so as not to further aggravate the world's increasingly uncertain situation.

\section{References}

Abdillah, L. A. (2020). Stigma Terhadap Orang Positif. In Masrul, L. A. Abdillah, Tasnim, J. Simarmata, Daud, O. K. Sulaiman, ... I. K. Soetijono, Pandemik COVID-19: Persoalan dan Refleksi di Indonesia (pp. 11-24). Yayasan Kita Menulis. 
Juanedi, Fajar dkk. 2020. Krisis Komunikasi dalam Pandemi Covid-19. Yogyakarta: Buku Litera.

Littlejohn, S. W., \& Foss, K. A. (2009). Encyclopedia of Communication Theory. California: SAGE Publications, Inc.

Moreno, Angeles; Fuentes-Lara, Cristina; Navarro, Cristina. 2020. "Covid-19 Communication Management in Spain: Exploring The Effect of Information-Seeking Behavior and Message Reception in Public's Eva'uation" dalam El Profesional de La Información Vol. 29 No. 4 (Hal. 1-16). Spanyol: Revista Internacional de Información y Comunicación.

Sativa. (2012). Keteladan dari Kampung Kauman Yogyakarta Sebagai Lingkungan Hunian yang Nyaman. Publikasi Ilmiah UMS, 35-40.

"Bahaya Stigma terhadap Mereka yang Berjuang Melawan Covid-19", https://tirto.id/bahaya-stigmaterhadap-mereka-yang-berjuang-melawan-covid-19-f5r1.

"Begini Awal Stigma Negatif Pasien Covid-19 Muncul di Masyarakat", https://www.suara.com/health/2020/10/21/142917/begini-awal-stigma-negatif-pasien-covid-19muncul-di-masyarakat?page $=$ all.

"Indonesia Peringkat 1 Negara di Asia Tenggara dengan Kasus Covid-19 Terbanyak", https://www.inews.id/lifestyle/health/indonesia-peringkat-1-negara-di-asia-tenggara-dengan-kasuscovid-19

terbanyak\#: :text=Indonesia\%20Peringkat\%201\%20Negara\%20di\%20Asia\%20Tenggara\%20denga n\%20Kasus\%20Covid\%2D19\%20Terbanyak,-

Riyandy\%20Aristyo\%20Sabtu\&text=JAKARTA\%2C\%20iNews.id\%20\%2D\%20Kasus,19\%20terti nggi\%20di\%20Asia\%20Tenggara.

"Kebersamaan Karakter Masyarakat Yogyakarta", http://biroumum.jogjaprov.go.id/index.php?option=com_content\&view=article\&id=147:kebersamaa n-karakter-masyarakat-yogyakarta\&catid=1:latest-news \&Itemid $=18$.

"Pasien Sembuh COVID-19 Bertambah Menjadi 781.147”, https://covid19.go.id/gejala-umum/pasiensembuh-covid-19-bertambah-menjadi-781147.

"Satgas: Stigma Negatif Pasien Covid-19 Masih Melekat Erat di Masyarakat", https://nasional.kompas.com/read/2020/12/21/15444351/satgas-stigma-negatif-pasien-covid-19masih-melekat-erat-di-masyarakat.

"Takut Stigma Negatif, Banyak Pedagang Pasar Tradisonal di Bantul Enggan Ikuti Rapid Test", https://jogja.tribunnews.com/2020/07/06/takut-stigma-negatif-banyak-pedagang-pasar-tradisonal-dibantul-enggan-ikuti-rapid-test.

“WHO Coronavirus Disease (COVID-19) Dashboard”, https://covid19.who.int/

\section{Copyrights}

Copyright for this article is retained by the author(s), with first publication rights granted to the journal.

This is an open-access article distributed under the terms and conditions of the Creative Commons Attribution license (http://creativecommons.org/licenses/by/4.0/). 